\title{
Determining and managing maize yield gaps in Rwanda
}

\section{Charles Bucagu $^{1}$ (1) $\cdot$ Alain Ndoli $^{2} \cdot$ Athanase R. Cyamweshi $^{3} \cdot$ Leon N. Nabahungu ${ }^{4} \cdot$ Athanase Mukuralinda $^{5}$. Philip Smethurst ${ }^{6}$}

Received: 2 July 2019 / Accepted: 22 June 2020 / Published online: 24 July 2020

(C) The Author(s) 2020

\begin{abstract}
Smallholder maize growers are experiencing significant yield gaps due to sub-optimal agricultural practices. Adequate agricultural inputs, particularly nutrient amendments and best management practices, are essential to reverse this trend. There is a need to understand the cause of variations in maize yield, provide reliable early estimates of yields, and make necessary recommendations for fertilizer applications. Maize yield prediction and estimates of yield gaps using objective and spatial analytical tools could provide accurate and objective information that underpin decision support. A study was conducted in Rwanda at Nyakiliba sector and Gashora sector located in Birunga and Central Bugesera agro-ecological zones, with the objectives of (1) determining factors influencing maize yield, (2) predicting maize yield (using the Normalized Difference Vegetation Index (NDVI) approach), and (3) assessing the maize yield gaps and the impact on food security. Maize grain yield was significantly higher at Nyakiliba $\left(1.74 \mathrm{tha}^{-1}\right)$ than at Gashora $\left(0.6 \mathrm{tha}^{-1}\right)$. NDVI values correlated positively with maize grain yield at both sites $\left(R^{2}=\right.$ 0.50 to 0.65$)$ and soil fertility indicators $\left(R^{2}=0.55\right.$ to 0.70$)$. Maize yield was highest at $40 \mathrm{~kg} \mathrm{P} h a^{-1}$ and response to $\mathrm{N}$ fertilizer was adequately simulated at Nyakiliba $\left(R^{2}=0.85\right.$, maximum yield $\left.3.3 \mathrm{tha}^{-1}\right)$. Yield gap was $4.6 \mathrm{tha}^{-1}$ in Nyakiliba and $5.1 \mathrm{tha}^{-1}$ in Gashora. Soil variables were more important determinants of social class than family size. Knowledge that low nutrient inputs are a major cause of yield gaps in Rwanda should prioritize increasing the rate of fertilizer use in these agricultural systems.
\end{abstract}

Keywords Maize grain yield $\cdot$ Social classification $\cdot$ Prediction $\cdot$ Crop intensification

\section{Introduction}

Electronic supplementary material The online version of this article (https://doi.org/10.1007/s12571-020-01059-2) contains supplementary material, which is available to authorized users.

Charles Bucagu

bucagucharles@gmail.com

1 University of Rwanda(UR), Busogo Campus - Musanze, Kigali, Rwanda

2 International Union for Conservation of Nature (IUCN), Kigali, Rwanda

3 Rwanda Agriculture and Animal Resources Development Board (RAB), Kigali, Rwanda

4 International Institute of Tropical Agriculture (IITA) -RDC, Bukavu, Democratic Republic of the Congo

5 International Centre for Research in Agroforestry, Huye, Rwanda

6 Commonwealth Scientific and Industrial Research Organisation (CSIRO) - Australia, Sandy Bay TAS, Australia
The main goal of agricultural crop management in a country is to guarantee food resources for its population. At the global level, the challenge is to feed about 7 billion people, a number which will most likely double by year 2050 (Ray et al. 2013). Food security requires coordinated action of a cross section of stakeholders in the food production chain. Governments in collaboration with various stakeholders are investing constant efforts to assure current human needs and preserve land quality for future generations (Kayiranga 2006). The largest proportion of agricultural production in developing countries comes from smallholder farmers and projections indicate the trend is likely to remain the same for at least the next 30 years (Thornton and Herrero 2001).

In the case of Rwanda, efforts are invested in promoting the crop intensification programme with the aim of increasing agricultural productivity of high potential food crops (maize, rice, wheat, cassava, Irish potato, and beans) for ensuring food security and self-sufficiency (Kathiresan 2011). Farm inputs (improved seeds, amendment such as lime and fertilizers) are distributed to farmers through public-private partnerships and 
extension services together with improved agricultural practices. As a result, agricultural productivity has been growing in recent years, translating into improved food security and household income (Kathiresan 2012).

Despite tangible success in terms of total production of maize and an expansion in total cultivated area, which increased from 28,016 to 286,412 ha from 2007 to 2013, crop yields remain far lower than their yield potential (MINAGRI 2014). For example, maize yield increased from $0.72 \mathrm{t} \mathrm{ha}^{-1}$ in 2007 to $2.34 \mathrm{t} \mathrm{ha}^{-1}$ in 2013 against the potential yield of $5 \mathrm{t} \mathrm{ha}^{-1}$. This yield gap may be due to several biotic and abiotic factors among which are pest and disease as well as nutrient deficiencies and climate change (FAO 2012).

Therefore, efforts meant for sustaining food production should target the farm and address all limiting factors associated with low productivity. In fact, performing seasonal yield assessment and building models for yield prediction can help to design mitigation strategies to avoid severe crop failures (Leng and Huang 2017).

Furthermore, numerous studies have recognized that plant development, stress, and yield capabilities are expressed in spectral reflectance from crop canopies and could be quantified using spectral vegetation indices such as the Normalized Difference Vegetation Index (NDVI) (Ahmad et al. 2014). The latter measures the amount of green vegetation in an area and is generally used to infer crop biomass and health over large areas where ground data are not available (Atzberger, 2013). At the time of maximum green leaf biomass development, NDVI has been shown to be highly correlated with final grain yield of cereals (Tucker et al. 1980) and can therefore be used to estimate in-season maize yield before harvesting while tracking factors undermining potential yield at farm level (Liu et al. 2012).

In Rwanda, NDVI-based studies integrating biotic, abiotic, and socio-economic factors that affect maize productivity are scanty and deserve focus. This study aimed at determining yield gap and devising appropriate strategies for managing maize yield gaps to ensure food security in Rwanda. Specifically, the study aimed at (1) characterizing farm-scale socio-economic and biophysical variables in relation to maize yield, (2) assessing the usefulness of the NDVI method for predicting maize yield and soil variable responses, and (3) estimating the maize yield gap and the impact on food security in relation to applied nutrients and other social variables.

\section{Materials and methods}

\subsection{Characteristics of the study locations}

The study was conducted in Bugesera and Rubavu districts as representatives of two contrasting agro-ecological (AEZ) zones of Rwanda (Fig. 1).
Bugesera district has a semi-arid climate with an annual rainfall of $850-1000 \mathrm{~mm}$, characterized by a bimodal rainfall pattern with primary and secondary peaks in April and November, respectively. The region has a dry season lasting for 3 months and an average temperature of about $21{ }^{\circ} \mathrm{C}$ (Verdoodt and Ranst 2003). Soils in Bugesera are very weathered and dominated by humic and haplic Ferralsols.

Rubavu district has a sub-humid climate with an annual rainfall varying between 1300 and $1600 \mathrm{~mm}$ (Verdoodt and Ranst 2003), with a bimodal pattern of 2 major cropping seasons: the "long rains" from mid-February to mid-July (named season B) and a "short rainy" season from September to January (named season A). Soils in this area are typically Mollic Andosols (Verdoodt and Ranst 2003) and cropping is dominated by a mix of various commodities including maize, Irish potato, and bean, with predominance of the climbing types. Nyakiliba and Gashora sectors were, respectively, selected within these districts as representatives of maizeproducing locations in 2015 and 2016 seasons. Biophysical characteristics, socio-economic indicators, and crop production systems of the research sites are reported in Table 1.

\subsection{Methodology}

The methodology applied a number of approaches and techniques to integrate various aspects that are critical to maize production. These approaches include a socio-economic survey and Normalized Difference Vegetation Index measurements coupled with remotely sensed and geo-information data. Process-based modelling of maize production was used to estimate yield gaps.

\subsubsection{Survey}

A survey was conducted in two contrasting regions, namely Bugesera district representing low altitude and low rains with frequent prolonged drought and Rubavu district, representing high altitude and rain intensity. The study sites were purposely chosen to reflect major contrasting cropland landscapes across Rwanda and therefore capture the large variability in terms of agricultural contexts under which Rwandan farmers operate. The two zones differ in terms of elevation, rainfall, temperatures, population size, and family structure.

The study targeted farmers in consolidated sites. To select representative farmers, a stratified sampling approach was applied. A field visit was organized with assistance of local leaders. In each district, three villages were randomly chosen and in each village three consolidated sites (upland, mid slope, and bottom land) were considered. The three villages were Kagako, Kiruhura, and Kagomasi in the Gashora sector and Bweza, Kibuye, and Kingoma in the Nyakiliba sector. In each village, three consolidated sites were selected. In each consolidated maize site, eight farmers having their plots in the same 


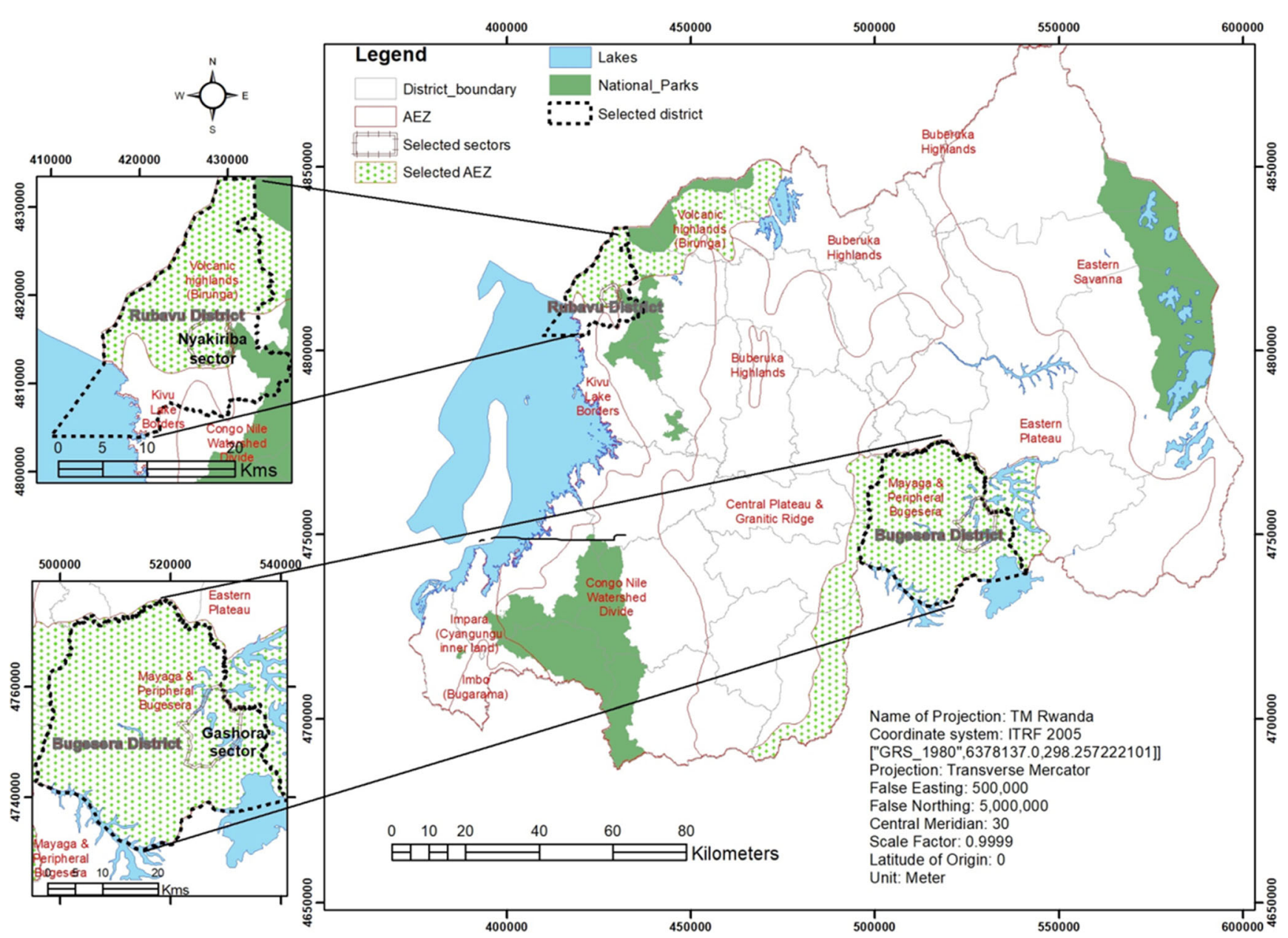

Fig. 1 Locations of Gashora and Nyakiliba, representing two contrasting agro-ecological zones

field were selected, making a total sample size of 144 farmers ( 2 districts $\times 3$ villages $\times 3$ consolidated sites $\times 8$ farmers) across both districts. Primary data covering socio-economic and management practices were collected from a total sample of 144 farmers through semi-structured interviews.

\subsubsection{Soil sampling and laboratory analysis}

At the start of the experiment, soil samples for this study were collected from Gashora and Nyakiliba sectors, respectively. In one individual farm, 3 samples were collected $(0-30-\mathrm{cm}$ depth) and mixed up and one composite sample extracted, dried, and submitted to the laboratory for soil analysis. The soil analysis was done for chemical and physical characterization. The parameters analysed were $\mathrm{pH}_{\mathrm{H} 2 \mathrm{O}}, \mathrm{pH}_{\mathrm{KCl}}$, soil organic carbon, nitrate, ammonium, available $\mathrm{P}$, clay, silt, and sand soil particles. The $\mathrm{pH}$ value in soil water suspension and $1 \mathrm{M} \mathrm{KCl}$ solution was determined in a 1:2.5 ratio using a potentiometer equipped with a combined $\mathrm{pH}$ meter. Soil particle size analysis was done using the hydrometer method (Bouyoucos 1962). Nitrogen (nitrates, ammonium) was determined using the colorimetric method, while organic carbon was determined using the method outlined in Walkley and Black (1934). Available phosphorus was determined using the molybdenum blue method on a Bray-P No. 1 extract (Bray and Kurtz 1945).

\subsubsection{Remotely sensed (NDVI measurement) and geo-information data}

The optical sensor Green Seeker helped to measure NDVI spectral reflectance of maize leaves. The Green Seeker provides measurements for two wavelengths (c. 660 and $770 \mathrm{~nm}$ ), enabling the calculation of the NDVI (Govaerts and Verhulst 2010). NDVI is computed by the following formula: NDVI $=($ NIR ref. - Red ref) / (NIR ref. + Red ref) (Gupta 2006). To understand the relationship existing between NDVI and final maize grain yield, we performed spatial statistical analysis of measured NDVIs and maize grain yield using Arc map 10.1 version. To explore correlation between maize grain yield and NDVI, we assumed that Yield $=f$ (NDVI) (Eq. 1). NDVIs and maize grain yield (GY) measurements were subjected to regression analysis. 
Table 1 Biophysical characteristics, socio-economic indicators, and crop production systems of the research sites, Nyakiliba and Gashora sectors, respectively

\begin{tabular}{|c|c|c|c|}
\hline \multirow[t]{2}{*}{ Variable } & \multirow[t]{2}{*}{ Units } & \multicolumn{2}{|l|}{ Sites } \\
\hline & & Nyakiliba & Gashora \\
\hline District & & Rubavu & Bugesera \\
\hline Agro-ecological zone & & Birunga & $\begin{array}{l}\text { Central Bugesera } \\
1401\end{array}$ \\
\hline${ }^{1}$ Altitude & $\mathrm{m}$ ASL & 2041 & $2^{\circ} 12^{\prime} 27^{\prime \prime} \mathrm{S}, 30^{\circ} 14^{\prime} 37^{\prime \prime} \mathrm{E}$ \\
\hline${ }^{2}$ Geographic coordinates & Degree & $1^{\circ} 55^{\prime} 09^{\prime \prime} \mathrm{S}, 29^{\circ} 44^{\prime} 14^{\prime \prime} \mathrm{E}$ & 98.8 \\
\hline${ }^{3}$ Area & $\mathrm{km}^{2}$ & 23.3 & \\
\hline${ }^{4}$ Rainfall & & & 900 \\
\hline Total annual rainfall & $\mathrm{mm}$ & 1500 & \\
\hline Rain distribution & & & September to November \\
\hline Short rains & & September to December & February to May \\
\hline Long rains & & February to May & Sandy loam \\
\hline${ }^{5}$ Soil texture (dominant) & & Sandy loam & \\
\hline \multicolumn{4}{|l|}{${ }^{6}$ Temperature } \\
\hline Annual mean & ${ }^{\circ} \mathrm{C}$ & 20 & 26 \\
\hline Annual maximum & ${ }^{\circ} \mathrm{C}$ & 25 & 30 \\
\hline Annual minimum & ${ }^{\circ} \mathrm{C}$ & 9 & 21 \\
\hline${ }^{7}$ Population density (2012) & \#inhab km ${ }^{-2}$ & 1039 (Rubavu average pop. density) & 280 (Bugesera average pop. density) \\
\hline${ }^{8}$ Dominant cropping systems & & $\begin{array}{l}\text { Mostly intensive crops with } \\
\text { predominance of Irish potatoes, } \\
\text { beans, maize, bananas, sorghum, } \\
\text { and vegetables }\end{array}$ & $\begin{array}{l}\text { Mostly intensive crops with } \\
\text { predominance of sweet potatoes, } \\
\text { beans, maize, bananas, cassava, } \\
\text { and soya beans }\end{array}$ \\
\hline
\end{tabular}

${ }^{1,2,5}$ Own data taken at field plot during study period (2015-2016); ${ }^{3,4,8} \mathrm{DDP}$ (district development plans for both Rubavu and Bugesera; ${ }^{6}$ REMA (2018);

${ }^{7}$ Rwanda statistical year book (2014)

\subsubsection{Estimating maize yield gap and implication on food security}

Experiments testing the response of maize to increasing $\mathrm{N}$ rates were installed at both Bugesera and Nyakiliba on farms in three villages per sector. The factorial experiment was run for two consecutive seasons: the short rain (SR) season 2015B (September 2015 to January 2016) and the long rain (LR) season in 2016A (February to May 2016). Plots of $20.25 \mathrm{~m}^{2}$ (4.5$\mathrm{m}$ length by $4.5-\mathrm{m}$ width) were used and the experiment was laid out in a randomized complete block design (RCBD) with 4 treatments $\left(4 \mathrm{~N}\right.$ rates consisting of $0,23,46$, and $92 \mathrm{~kg} \mathrm{~N} \mathrm{ha}^{-1}$ as urea with a blanket application of $36 \mathrm{~kg} \mathrm{~N}$ and $40 \mathrm{~kg} \mathrm{P} \mathrm{ha}^{-1}$ as DAP). Maize (variety Pool 9A in Nyakiliba, PAN 691 in Bugesera) was established at $75 \mathrm{~cm} \times 25 \mathrm{~cm}$ spacing between and within rows and thinned to one plant per hill. Plots were hand-weeded twice during the growing season.

The APSIM framework is a reputable, process-based, suite of one-dimensional daily crop, pasture, and tree models that can be linked in the software with livestock and farm-scale livelihood models. This framework has been successfully used internationally for simulating production under a range of crop, soil, climate, and management options for risk assessment in a wide range of production systems (Holzworth et al. 2018). The APSIM maize model is particularly suited to Rwanda, because it has a long history of use in development, testing, and use in East Africa (e.g. Smethurst et al. (2017)). The model was calibrated using data from the experimental control plots. Values of soil water contents used to set soil drainage parameters, namely lower and upper drained limits, were extracted from Ndoli et al. (2017) who measured soil moisture in the vicinity of our research area and in similar period. Measured soil carbon and $\mathrm{N}$ were used to initialize the model. Maize cultivars sown were not available in the model, but phenology and morphology parameters were approximated by simulating maize cultivar SC623. The parameter determining the cumulative temperature until the end of the juvenile period was set to $280^{\circ} \mathrm{C}$ days in order to match the phenology observed during the experiment. The maximum number of kernels per maize ear was set to 504. Maize yield gaps were estimated by comparing measured experimental yield data with simulated yields using the APSIM Next Generation framework of models (Holzworth et al. 2018).

Grain fresh weight and grain moisture content (using a moisture meter) were measured and grain weight adjusted to $12 \%$ moisture. The simulations estimated (a) the response to $\mathrm{N}$ 
fertilizer in presence of $\mathrm{P}$ fertilizer and (b) potential maize yield from hypothetically high $\mathrm{N}$ fertilizer rates that simulated yield with no $\mathrm{N}$ stress. Weather data were provided by the Rwanda Meteorology Agency. Management input variables, including sowing date, sowing density, fertilizer application, and fertilizer amount, were set according to each field experiment. The model was tuned to provide no water stress and a soil $\mathrm{N}$ supply that approximately reflected observed yields across the range of $\mathrm{N}$ fertilizer rates used. The yield gap was then assessed by subtracting measured maize yield from APSIM-predicted maize yield using the $\mathrm{N}$ fertilizer rate that eliminated $\mathrm{N}$ stress (simulated). The Nash-Sutcliffe modelling efficiency (NSE) and the root mean square error to standard deviation ratio (RSR) were used to evaluate model performance.

Yield gaps were also expressed in terms of food security indicators (amount of proteins and calories) for which the values of food energy and protein were derived using the average energy and protein content in maize estimated to be $342 \mathrm{kcal} / 100 \mathrm{~g}$ of energy and $9 \mathrm{~g} / 100 \mathrm{~g}$ of protein on dry matter basis (Bucagu et al. 2014).

\subsubsection{Discriminant analysis}

Discriminant analysis (Statgraphics@ $@$ software) was performed to investigate the extent to which descriptors (various qualitative and quantitative variables) could correctly classify maize yield, income, or social class. All dependent variables were defined as categorical variables.

\subsection{Data analysis}

The results were processed using SPSS 21 software for statistical analysis of baseline survey data (socio-economic). The results from soil chemical and physical analysis were compared using the GenStat ANOVA procedure. Predicted maize yield determined using the APSIM model was compared against the measured maize yield.

\section{Results}

\subsection{Socio-economic characteristics}

The results from the survey indicate that the average family size was 4 members per family in both sectors, but with a larger range from 1.5 to 10 in Gashora compared with 1.5 to 8 in Nyakiliba (Fig. 2). The family members comprise household heads, spouse, and children. The number of women headed households was higher in Gashora (52\%) than in Nyakiliba (43\%).

In the two study areas, most farmers surveyed had an average of 0.27 and 0.08 ha of land under maize cultivation in Gashora and Nyakiliba, respectively. These are individual maize plots merged with neighbouring plots but farmers retaining their land rights. Results indicate livestock ownership and distribution in both Gashora and Nyakiliba districts.

In Gashora, $69 \%$ of farmers own livestock. Among them, $19 \%$ of farmers own at least a cow, $4 \%$ a sheep, $28 \%$ at least a goat, $7 \%$ at least a hen, and $1 \%$ a pig. In Nyakiliba, $65 \%$ own either a small ruminant or a large livestock. Among them, $18 \%$ own a cow, $23 \%$ at least a goat, and $7 \%$ at least a hen. Some farmers have more than one type of livestock, e.g. a cow and goats (15\%), and goats and pigs (7\%) (Fig. 2). The estimated quantity of maize harvested largely varies from 50 to $2600 \mathrm{~kg}$ per household in both Nyakiliba and Gashora while the sold quantity of maize varies from 0 to $400 \mathrm{~kg}$ per household, representing $15 \%$ of total maize harvested.

\subsection{Soil characteristics}

Results of soil laboratory analysis are presented in Table 2. In both locations, soil $\mathrm{pH}$ was slightly acidic and falls in the range of 5.4 to 6.1 in Nyakiliba and 4.9 to 6.7 in Gashora. The values of $\mathrm{N}$, available $\mathrm{P}$, and $\mathrm{OM}$ significantly differed $(P<0.001)$ in the two locations. In Nyakiliba, nitrogen was 4.4 times higher in the Nyakiliba site (28.6 ppm) than in Gashora (6.36 ppm). Results show that the Nyakiliba sector had higher concentrations of soil organic carbon $(2.81 \%)$ than Gashora (1.67\%) (Table 2) but Gashora had higher concentration of available P (8.0 ppm) than Nyakiliba (3.0 ppm). Soil slope was classified as steep slope $(>30 \%)$ in $41 \%$ of cases in Gashora and $15 \%$ of cases in Nyakiliba. The soil texture was sandy loam in both study sites, with the presence of rocky material in some areas in Nyakiliba.

\subsection{Management practices}

In general, major agricultural practices conducted in maizeproducing areas are ploughing, soil amendment, fertilizer application, weeding, integrated pest and disease management (IPM), and crop residue management. In Gashora, only a handful of farmers do an early ploughing and none in Nyakiliba, but all farmers plough once immediately before maize sowing. All farmers in both locations use organic fertilizers combined with mineral fertilizers. In Nyakiliba, all farmers practice maize plant thinning, while it is only done by a smaller percentage of farmers $(11.1 \%)$ in Gashora. Weeding and pest and disease management are consistently done in both locations but few farmers recycle maize residues/stover (5.4\%).

Management practices consisted of erosion control measures, mainly installation of ditches and terraces. In 2015 and 2016A cropping seasons, majority of farmers in Gashora cultivated beans while those in Nyakiliba cultivated beans in association with maize. The reason for the predominant crop mixing system in Gashora is linked with erratic weather conditions that prevail in the region and farmers strategizing for minimizing 
(a)
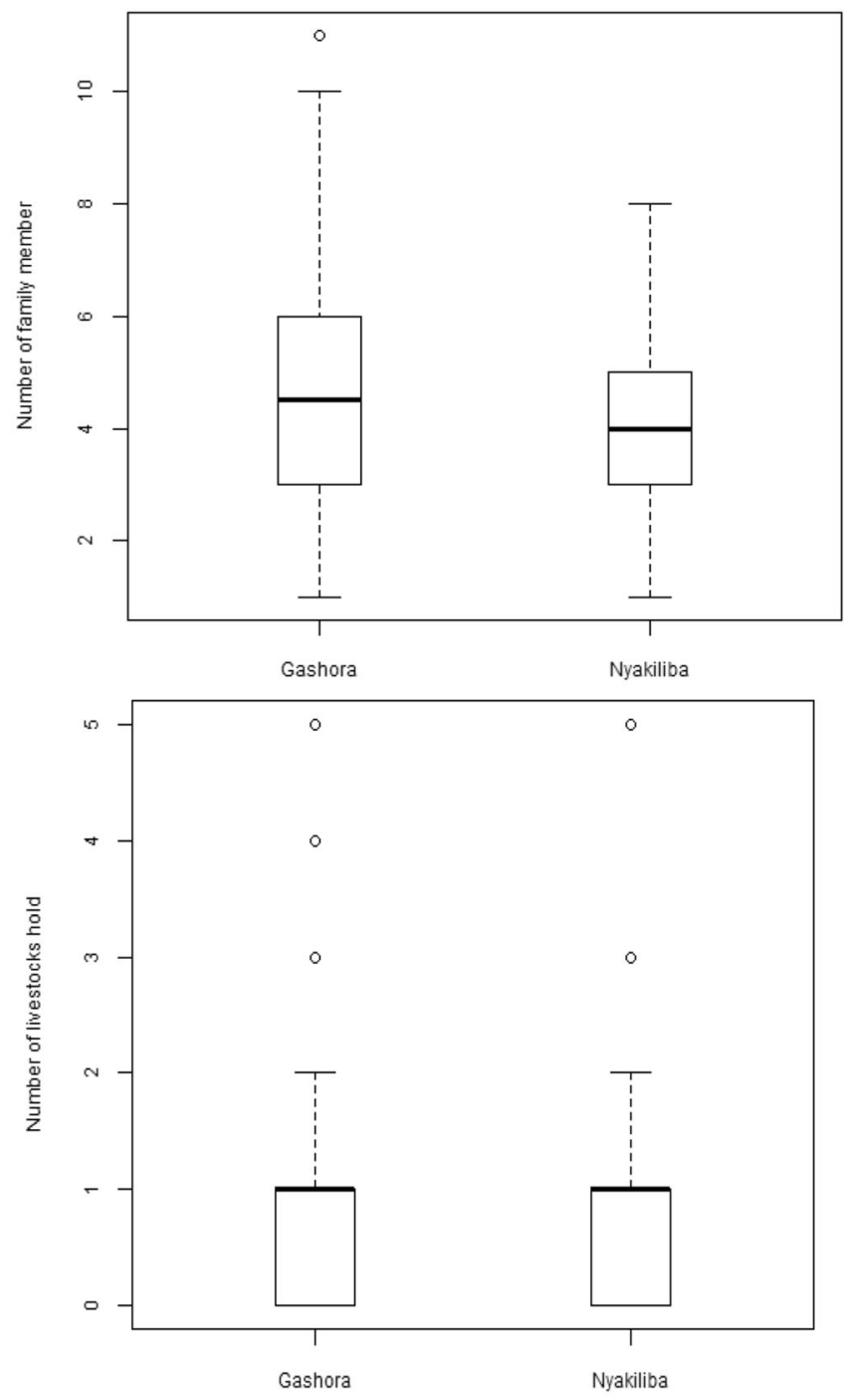

(c) (b)
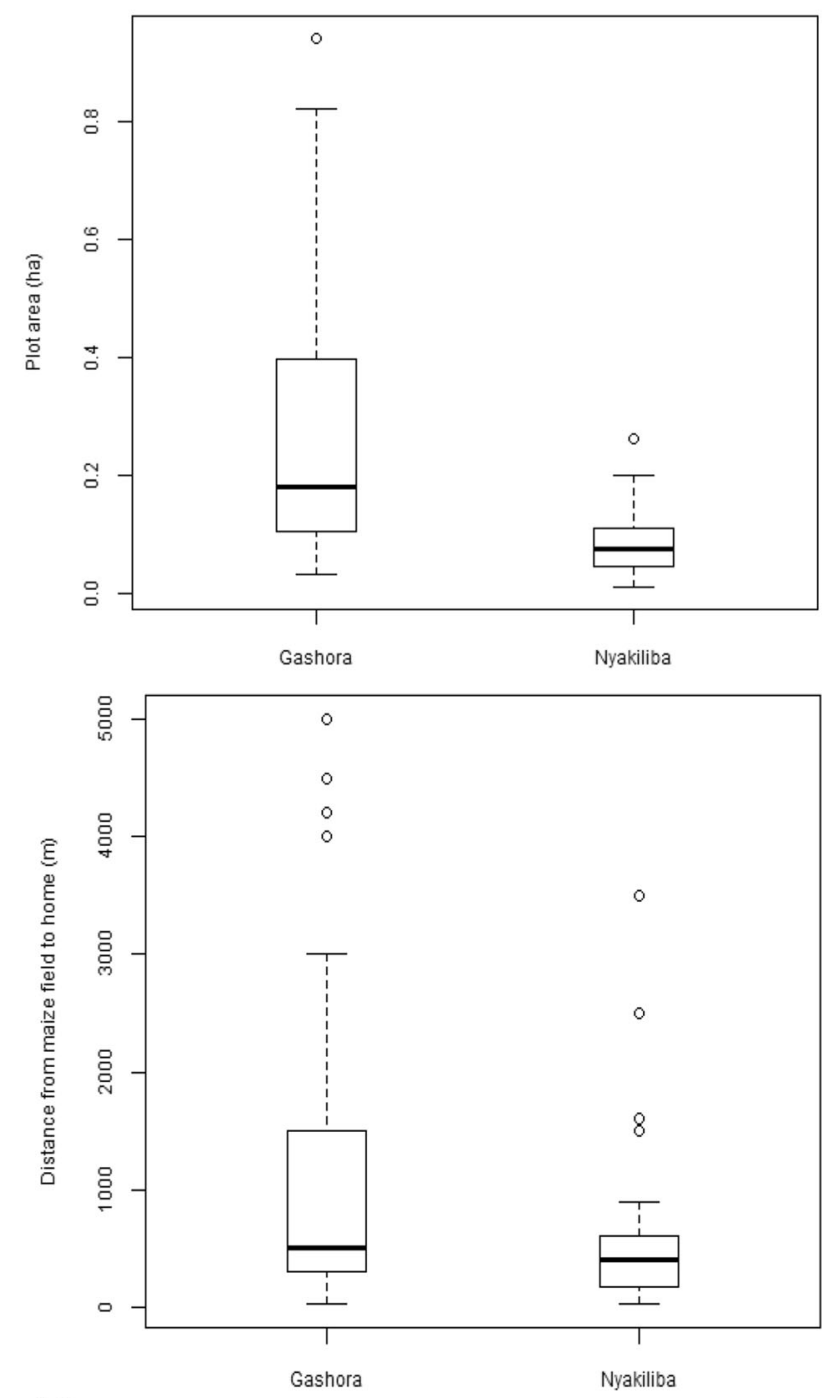

Fig. 2 a-d Major socio-economic characteristics in Gashora and Nyakiliba sectors

risks of food insecurity by practicing mixed cropping. This strategy, in the anticipation of a possible shortage of rain in the region, maximizes the chance of harvesting at least some beans, which have a short growth cycle.

\subsection{Prediction of maize yield using the NDVI method}

Correlation between NDVI and relative maize grain yield is illustrated in Fig. 3. The results indicated a significant $(P<0.05)$ and a positive and weak to moderate relationship between the relative maize yield and NDVI. In the cropping season 2015A, the coefficients of regression $R^{2}$ corresponded to 0.52 and 0.61 in Nyakiliba and Gashora, respectively, while in $2015 \mathrm{~B}$, the coefficients were 0.50 and 0.65 respectively in the mentioned sites. In all cases, maize yield increased with
NDVI; however, the yield plateau reached at an NDVI of 0.8 beyond which no more yield increase was recorded (Fig. 3).

\subsection{Relationship between NDVI and soil fertility parameters}

Figure 4 illustrates the relationship between NDVI and soil fertility parameters. The results indicate positive linear relationships between NDVI and all measured soil parameters with $R^{2}$ values ranging from 55 to $70 \%$. Correlation coefficients are much larger for Gashora than Nyakiliba except for $\mathrm{NO}_{3}-\mathrm{N}$. SOC explained about 67 and $55 \%$ of variation in NDVI in Nyakiliba and Gashora respectively; $\mathrm{NO}_{3}-\mathrm{N}$ explained 69 and $70 \%$ of variation in NDVI in Nyakiliba and Gashora respectively while $\left(\mathrm{NO}_{3}-\mathrm{N}+\mathrm{NH}_{4}\right)$ explained 59 and 
Table 2 Physical and chemical soil characteristics for Gashora and Nyakiliba sites

\begin{tabular}{|c|c|c|c|c|c|c|c|c|}
\hline \multirow{2}{*}{$\begin{array}{l}\text { Chemical and } \\
\text { physical properties }\end{array}$} & \multirow[t]{2}{*}{ Unit } & \multicolumn{3}{|c|}{ Nyakiliba } & \multicolumn{3}{|c|}{ Gashora } & \multirow{2}{*}{$\begin{array}{l}\text { Sign. difference } \\
\text { levels }\end{array}$} \\
\hline & & Mean & Range & SE & Mean & Range & SE & \\
\hline $\mathrm{pH}_{(\mathrm{H} 2 \mathrm{O})}$ & - & 5.85 & 0.66 & 0.032 & 5.91 & 1.66 & 0.07 & NS \\
\hline $\mathrm{pH}\left({ }_{\mathrm{KCl}}\right)$ & - & 5.41 & 0.64 & 0.032 & 5.38 & 1.95 & 0.08 & NS \\
\hline $\mathrm{C}$ & $\%$ & 2.81 & 1.00 & 0.076 & 1.67 & 1.00 & 0.09 & $* * *$ \\
\hline Org. matter & $\%$ & 4.73 & 2.81 & 0.126 & 2.84 & 2.14 & 0.10 & $* * *$ \\
\hline $\mathrm{NH}_{4}^{+}-\mathrm{N}$ & ppm & 5.93 & 4.38 & 0.226 & 0.71 & 3.09 & 0.22 & $* * *$ \\
\hline $\mathrm{NO}_{3}{ }^{2}-\mathrm{N}$ & ppm & 28.26 & 50.75 & 2.602 & 6.36 & 30.29 & 1.44 & $* * *$ \\
\hline P avail. & ppm & 3.00 & 6.00 & 0.287 & 8.00 & 25.00 & 0.96 & $* * *$ \\
\hline Clay & $\%$ & 7 & 0 & 1.49 & 21 & 16 & 0.58 & $* * *$ \\
\hline Silt & $\%$ & 29 & 2 & 0.72 & 14 & 18 & 0.72 & $* * *$ \\
\hline Sand & $\%$ & 64 & 2 & 1.24 & 65 & 6 & 0.43 & NS \\
\hline Texture class & & \multicolumn{3}{|c|}{ Sandy loam } & \multicolumn{3}{|c|}{ Sandy loam } & \\
\hline
\end{tabular}

*** Significant at $P<0.0001$. NS no significant differences
$69 \%$. Phosphorus explained 60 and $63 \%$ of NDVI variation respectively in Nyakiliba and Gashora.

\subsection{Maize grain yield and yield gap and implication on food security}

Maize yield was affected by the main effect of $\mathrm{P}$ rate and interaction between $\mathrm{N}$ and $\mathrm{P}$ rates (Table 3 ). In Gashora, maize yield was the lowest in the absence of $\mathrm{P}$ and the highest with $\mathrm{P}$ applied at $40 \mathrm{~kg} \mathrm{ha}^{-1}\left(1.08 \mathrm{tha}^{-1}\right)$ compared with the control. Interaction between $\mathrm{N}$ and $\mathrm{P}$ affected significantly maize yield at $\mathrm{N}$ applied at 10 and $20 \mathrm{~kg} \mathrm{ha}^{-1}$ as compared with the control without fertilizers. $\mathrm{N}$ applied at $40 \mathrm{~kg} \mathrm{ha}^{-1}$ combined with $\mathrm{P}$ at $92 \mathrm{~kg} \mathrm{ha}^{-1}$ had the highest effect on maize yield $\left(1.2 \mathrm{t} \mathrm{ha}^{-1}\right)$.

In Nyakiliba, maize response to $\mathrm{P}$ was much larger but with similar trend as in Gashora. Maize yield was the highest with $40 \mathrm{~kg} \mathrm{ha}^{-1}\left(2.1 \mathrm{t} \mathrm{ha}^{-1}\right)$, significantly higher than the control without P. Interaction between $\mathrm{N}$ and $\mathrm{P}$

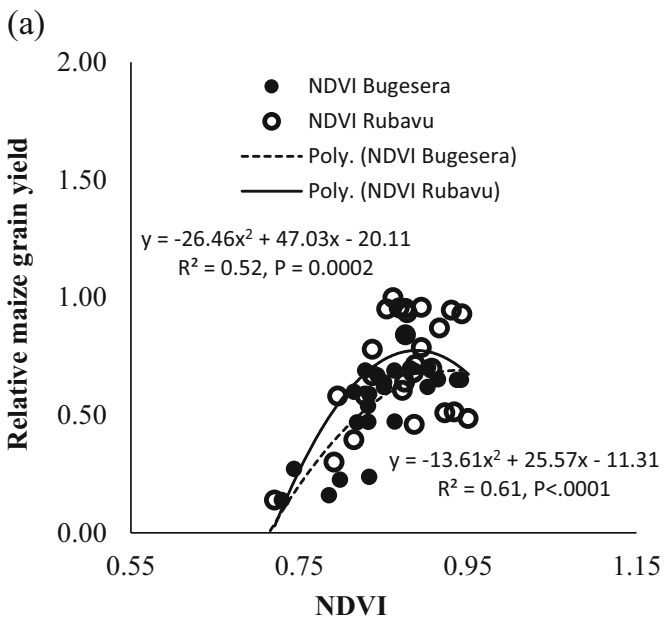

affected significantly maize yield at $\mathrm{N}$ applied at 10 and $20 \mathrm{~kg} \mathrm{ha}^{-1}$ as compared with the control. $\mathrm{N}$ applied at $40 \mathrm{~kg} \mathrm{ha}^{-1}$ combined with $\mathrm{P}$ at $92 \mathrm{~kg} \mathrm{ha}^{-1}$ had the highest effect on maize yield $\left(2.1 \mathrm{t} \mathrm{ha}^{-1}\right)$.

The response of maize grain yield to $\mathrm{N}$ fertilizer was adequately simulated at Nyakiliba in the presence of $\mathrm{P}$ fertilizer $\left(R^{2}=0.85\right.$, maximum yield $\left.3.5 \mathrm{tha}^{-1}\right)$, but the maximum rate of fertilizer used $\left(92 \mathrm{~kg} \mathrm{~N} \mathrm{ha}^{-1}\right.$ ) was simulated to be inadequate to maximize $\mathrm{N}$-sufficient yield $\left(8.1 \mathrm{t} \mathrm{ha}^{-1}\right.$, Fig. 5). Hence, at the highest rate of $\mathrm{N}$ fertilizer used, the yield gap was $4.6 \mathrm{tha}^{-1}$, meaning farmers may be able to only produce $43 \%$ of the maximum maize yield. The gap was simulated to increase to $6.5 \mathrm{t} \mathrm{ha}^{-1}$ if no $\mathrm{N}$ fertilizer was applied, translating into $80 \%$ of total potential yield in the case of $\mathrm{N}$-sufficient yield. The yield gap can be expected to be higher in the absence of $\mathrm{P}$ fertilizer, and higher rates of $\mathrm{P}$ and other fertilizers are likely to be needed to attain maximum grain yield. At Gashora, the observed response to $\mathrm{N}$ fertilizer could not be

(b)

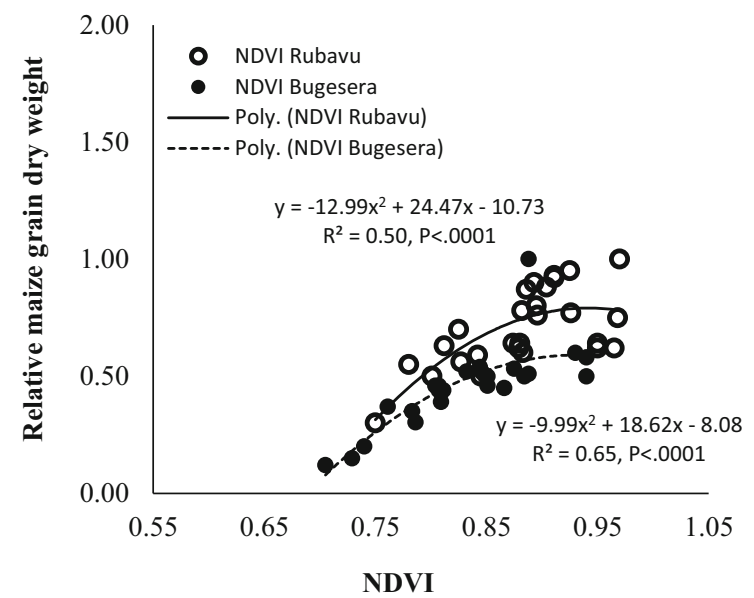

Fig. 3 Correlation between NDVI and relative maize grain yield during season 2015A (a) and season 2015B (b) 
Fig. 4 a-h Relationship between field mean NDVI and soil fertility parameters (a)
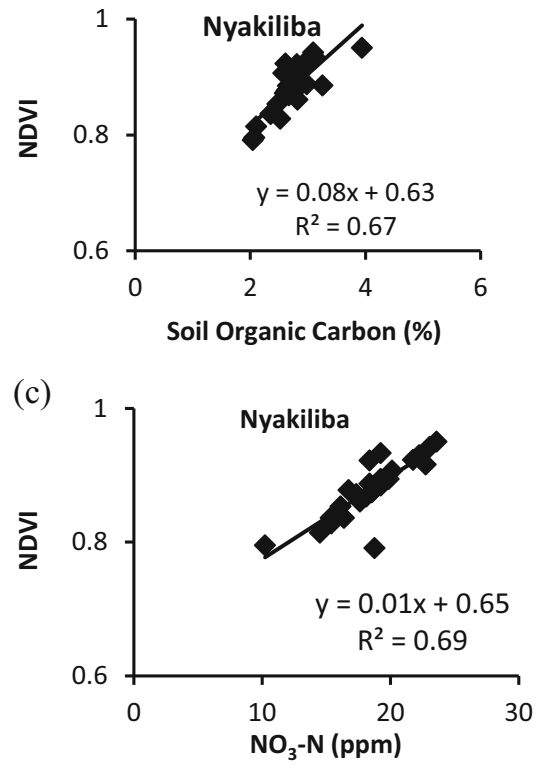

(e)

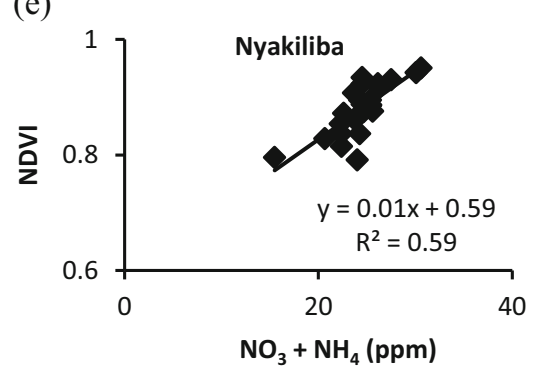

(g)

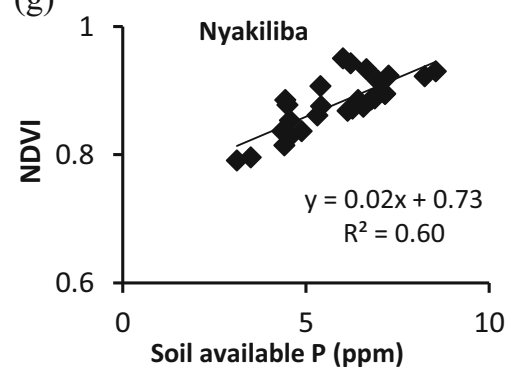

(b)

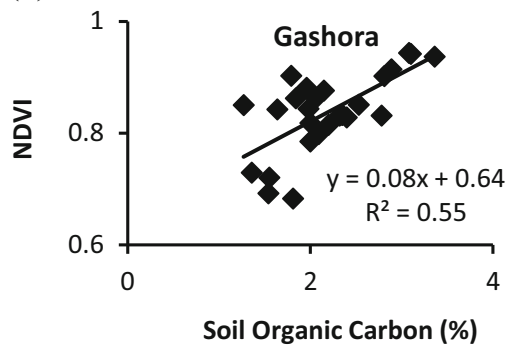

(d)

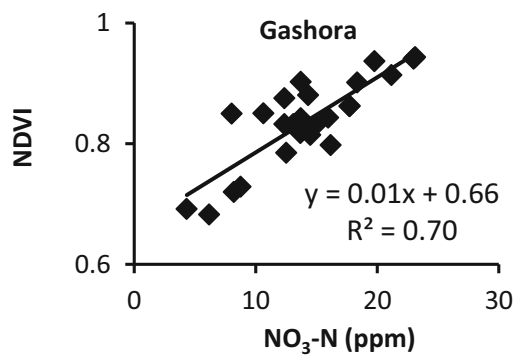

(f)

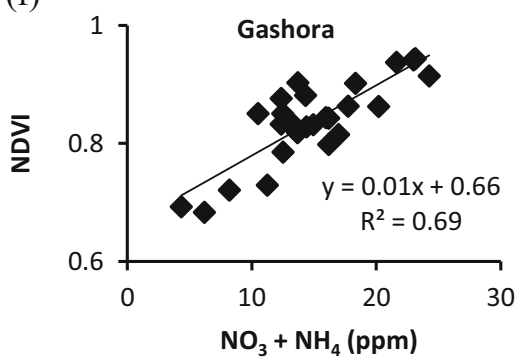

(h)

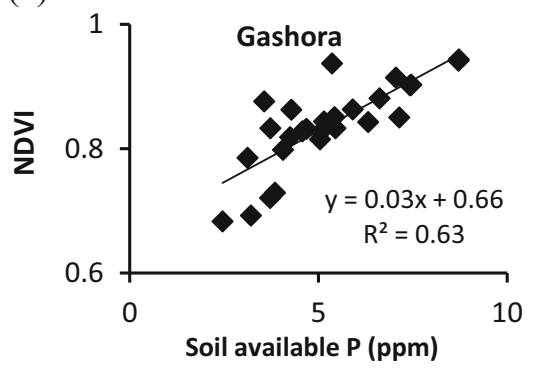

adequately simulated because simulated yields could not be reduced enough by limiting water and $\mathrm{N}$ supply alone in the APSIM model. Water and N-sufficient simulated yield at Gashora was $6.3 \mathrm{t} \mathrm{ha}^{-1}$, which indicates a yield gap of at least $5.1 \mathrm{tha}^{-1}$.

The level of maize yield gap in Nyakiliba and Gashora translates into 15,721 to $22,178 \mathrm{kcal} \mathrm{ha}^{-1}$ and 416 to $587 \mathrm{~g}$ of proteins under various $\mathrm{N}$ rates. Estimated monetary losses range from 1664 to 2348 USD on per hectare basis. In Gashora, the levels are respectively 17,442 kcal and $459 \mathrm{~g}$ of protein at $92 \mathrm{~kg} \mathrm{~N} \mathrm{ha}^{-1}$ (Table 4).

\subsection{Discriminant analyses for maize yield, income, and social class}

A function for income category was significant, which correctly predicted $42 \%$ of cases. When maize yield, income, and soil factors were included, social category was correctly and significantly $(P<0.01)$ predicted in $74 \%$ of cases. Variables with large standardized coefficients that strongly predict social category were income $>$ maize type $>$ soil local name $>$ soil texture (Table 5). The number of years the farm had been used, the number of livestock, the level of soil fertility, and 
Table 3 Grain yield of maize as affected by the interaction effects of different levels of $\mathrm{N}$ and $\mathrm{P}$ fertilizer application in Gashora and Nyakiliba

\begin{tabular}{|c|c|c|c|c|c|}
\hline \multicolumn{6}{|l|}{ Gashora } \\
\hline \multirow[b]{2}{*}{$\mathrm{N}$ levels $\left(\mathrm{kg} \mathrm{ha}^{-1}\right)$} & \multicolumn{5}{|c|}{ P levels $\left(\mathrm{kg} \mathrm{ha}^{-1}\right)$} \\
\hline & $\mathbf{0}$ & 10 & 20 & 40 & Average \\
\hline 0 & 571.2 & 693.9 & 779.0 & 953.1 & 749.3 \\
\hline 23 & 656.4 & 728.7 & 808.4 & 1080.5 & 818.5 \\
\hline 46 & 658.1 & 733.8 & 812.6 & 1109.1 & 828.4 \\
\hline 92 & 673.6 & 768.2 & 878.2 & 1201.6 & 880.4 \\
\hline Average & 639.8 & 731.1 & 819.5 & 1086.1 & 819.1 \\
\hline$P$ value $(\mathrm{P})$ & & $<0.001$ & & & \\
\hline$P$ value $(\mathrm{N} \times \mathrm{P})$ & & $<0.001$ & & & \\
\hline SED (P) & & 102.7 & & & \\
\hline $\operatorname{SED}(\mathrm{N} \times \mathrm{P})$ & & 87.8 & & & \\
\hline \multicolumn{6}{|l|}{ Nyakiliba } \\
\hline $\mathrm{N}$ levels $\left(\mathrm{kg} \mathrm{ha}^{-1}\right)$ & $\mathbf{0}$ & 10 & 20 & 40 & Average \\
\hline 0 & 1010.7 & 1667.3 & 1810.5 & 2077.2 & 1641.4 \\
\hline 23 & 1168.7 & 1806.6 & 1812.5 & 2121.4 & 1727.3 \\
\hline 46 & 1210.6 & 1820.9 & 1817.2 & 2191.6 & 1760.1 \\
\hline 92 & 1215.0 & 1825.0 & 1817.4 & 2201.8 & 1764.8 \\
\hline Average & 1151.2 & 1779.9 & 1814.4 & 2148.0 & 1723.4 \\
\hline$P$ value $(\mathrm{P})$ & & $<0.001$ & & & \\
\hline$P$ value $(\mathrm{N} \times \mathrm{P})$ & & $<0.001$ & & & \\
\hline SED (P) & & 265.7 & & & \\
\hline $\mathrm{SED}(\mathrm{N} \times \mathrm{P})$ & & 254.3 & & & \\
\hline
\end{tabular}

the inter-row maize spacing were variables with the strongest predictability of farmer income (data not presented). Soil variables were more important determinants of social class than family size. On the other hand, family size had only a relative importance of $23 \%$ for maize production.

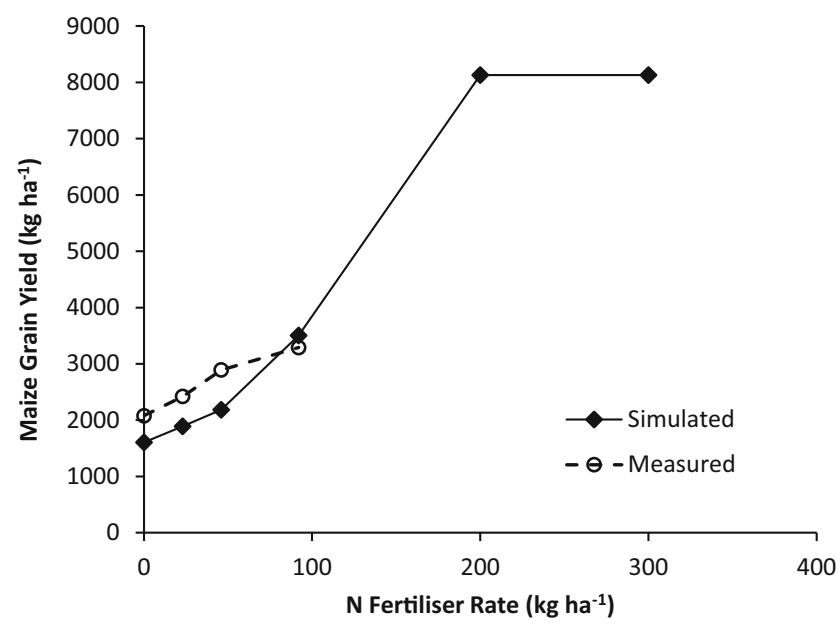

Fig. 5 Simulated and measured maize grain yield at Nyakiliba (Rubavu) in season B 2015

\section{Discussion}

The choice of contrasting locations (Nyakiliba and Gashora) lies in the fact they differ from each other, giving a broader representation of country's contexts of farmer cropping environment, climate, and soil type of Rwanda. Nyakiliba located in Birunga AEZ receiving sufficient rains and covered by Andosols (volcanic soils) and Gashora located in Central Plateau AEZ differ in terms of soil type and climatic conditions, resulting in higher maize productivity in Nyakiliba due to conducive climate (Table 1) and better soil fertility (Table 2). Both locations also differ in terms of socialeconomic aspects (family structure). These factors are known to significantly influence crop productivity in Africa (Bucagu et al. 2014). Efforts to reduce crop yield gap require identification of underlying factors that determine it at farm level and these are location specific (Tittonell et al. 2008; Van Ittersum et al. 2013; Beza et al. 2017).

\subsection{Factors influencing maize yield gap}

Our analysis looked at the extent to which biophysical and socio-economic factors predict maize production in the study sites (Table 5). The number of years the farm has been cultivated, the number of livestock holds, and the level of soil fertility seem to be major predictors of maize production on farm. Family size predicts about $23 \%$ of maize production. Maize inter-row spacing seems to also significantly influence maize production in both sites. In Gashora, farmers tend to adopt intercropping rather than a monocrop intensification programme, resulting in poor maize planting density and contributing to lesser maize yield. Maize yield was twice as high and the response of maize grain yield to fertilizer was much stronger in Nyakiliba compared with Gashora. This is attributed to the varying biophysical conditions, similarly to the trend observed by Sileshi et al. (2010). Yield gap determined at the global level, using a single crop model to simulate generic crop yields, indicated limitations in terms of comparison between countries (Van Ittersum et al. 2013). In Kenya, maize yield gap was attributed to varying soil and management decisions by farmers (Tittonell et al. 2008).

Maize yield differed significantly with $\mathrm{P}$ rates and interaction between $\mathrm{N}$ and $\mathrm{P}$. The highest maize yield was obtained with $\mathrm{P}$ applied at rate of $40 \mathrm{~kg} \mathrm{ha}^{-1}$ (Table 3). The level of maize yield gap in Nyakiliba translates into a substantial amount of 15,721 to $22,178 \mathrm{kcal} \mathrm{ha}^{-1}$ and 416 to $587 \mathrm{~g}$ of proteins under various $\mathrm{N}$ rates, respectively (Table 4). Estimated monetary losses range from 1664 to 2348 USD on per hectare and per year basis in Nyakiliba. In Gashora, the levels are respectively $17,442 \mathrm{kcal}$ and $459 \mathrm{~g}$ of protein at $92 \mathrm{~kg} \mathrm{~N} \mathrm{ha}{ }^{-1}$.

Based on the minimum calories and protein requirements of $0.8 \mathrm{~g}$ protein day ${ }^{-1}$ person ${ }^{-1} \mathrm{~kg}^{-1}$ body weight (for a body 
Table 4 Estimated amount of calories, proteins, and monetary values corresponding to the levels of maize yield gaps at various $\mathrm{N}$ rates $\left(\mathrm{kg} \mathrm{ha}^{-1}\right)$

\begin{tabular}{|c|c|c|c|c|c|}
\hline Site & $\mathrm{N}$ rate & $\begin{array}{l}\text { Yield } \\
\text { gaps }\end{array}$ & $\begin{array}{l}\text { Estimated } \\
\text { calories }\end{array}$ & $\begin{array}{l}\text { Estimated } \\
\text { protein }\end{array}$ & $\begin{array}{l}\text { Estimated* monetary value } \\
\text { (USD) }\end{array}$ \\
\hline \multirow[t]{5}{*}{ Nyakiliba } & $\left(\mathrm{kg} \mathrm{ha}^{-1}\right)$ & $\left(\mathrm{kg} \mathrm{ha}^{-1}\right)$ & $\left(\mathrm{kcal} \mathrm{ha}^{-1}\right)$ & $\left(\mathrm{g} \mathrm{ha}^{-1}\right)$ & \\
\hline & 0 & 6523 & $22,178.2$ & 587.07 & 2348.28 \\
\hline & 23 & 6241 & $21,219.4$ & 561.69 & 2246.76 \\
\hline & 46 & 5946 & $20,216.4$ & 535.14 & 2140.56 \\
\hline & 92 & 4624 & $15,721.6$ & 416.16 & 1664.64 \\
\hline
\end{tabular}

*Assuming $1 \mathrm{~kg}$ of maize grain cost 0.36 USD (exchange rate: BNR, 2016) weight of $60 \mathrm{~kg}$ ) and $2250 \mathrm{kcal}_{\text {person }}{ }^{-1}$ day $^{-1}$ (Trumbo et al. 2002), a single farmer would be in a position to cater for the basic food requirement of at least 8 more adult people in 1 day, if he/she manages to fill the maize yield gap on 1 ha of land in Nyakiliba. With about 5400 ha of estimated maize harvested area for Rubavu district (MINAGRI 2014), a scenario with maximized maize yield on a single hectare of maize area would translate into additional food production (i.e. for 15 adult people for 1 year) towards sustainable improvement in food security.

\subsection{Use of NDVI in crop yield estimate and soil fertility response}

Use of NDVI was introduced here to indicate a flexible method to determine farmer yield at any time during the course of the season and relate this to the soil fertility level. The study highlighted a positive relationship between sensed Normalized Difference Vegetation Index and field level yield (Fig. 3) and is in agreement with studies done by Teal et al. (2006), where a strong relationship was achieved between NDVI-measured indices using a Green Seeker sensor and maize grain yield. In the cropping season $2015 \mathrm{~A}$, the coefficients of regression $R^{2}$ corresponded to 0.52 and 0.61 in Nyakiliba and Gashora, while in $2015 \mathrm{~B}$, the coefficients were 0.50 and 0.65 , respectively. The results of this study are also in line with the studies of Ray et al. (2003) and Gat et al. (2000). The NDVI has been shown to be highly correlated with the final grain yield of cereals around the time of maximum green leaf biomass development (Tucker et al. 1980).

The study indicated a moderate to strong relationship between NDVI and soil fertility parameters (Fig. 4) with $R^{2}$ values ranging from 55 to $70 \%$. A strong relationship between NDVI and most soil nutrients, especially $\mathrm{N}$ and $\mathrm{P}$, is a clear evidence of the contribution of the soil nutrients in explaining plant growth and development (Fig. 4). $\mathrm{N}$ and $\mathrm{P}$ are reported to be key limiting nutrients in sub-Saharan Africa (SSA) and particularly in the East African highlands (Shepherd et al. 1995; Kelly et al. 2002). The establishment of the relationship between NDVI (proxy of maize yield) and key soil nutrients could potentially offer possibilities of prediction of relative maize yield using simple linear regression relationship in the specific locations.

Table 5 Summary of discriminant functions

\begin{tabular}{|c|c|c|c|c|}
\hline \multirow[t]{2}{*}{ Attribute } & \multicolumn{4}{|l|}{ Dependent variable } \\
\hline & $\begin{array}{l}\text { Maize yield } \\
\text { category }\left(\mathrm{t} \mathrm{ha}^{-1}\right)\end{array}$ & $\begin{array}{l}\text { Maize yield } \\
\text { category }\left(\mathrm{t} \text { farm }^{-1}\right)\end{array}$ & Income category (RWF) & Social category \\
\hline Correctly predicted cases (\%) & 35 & 46 & 42 & 74 \\
\hline Probability level & 0.07 & $<0.01$ & $<0.01$ & $<0.01$ \\
\hline Predictors & $\begin{array}{l}\text { - ha of cultivated area } \\
\text { - Organic fertilizer used } \\
\text { - Number of seeds } \\
\text { sown per hole }\end{array}$ & $\begin{array}{l}\text { - Years of agriculture } \\
\text { - \% land cultivated } \\
\text { - Number of livestock } \\
\text { - Number of family members } \\
\text { - Soil depth }\end{array}$ & $\begin{array}{l}\text { - Organic fertilizer used } \\
\text { - Number of seeds sown per hole } \\
\text { - Spacing of inter-rows }\end{array}$ & $\begin{array}{l}\text { - Soil colour } \\
\text { - Soil texture } \\
\text { - Soil depth } \\
\text { - Soil local name } \\
\text { - Erosion control } \\
\text { - First plough } \\
\text { - Organic fertilizer used } \\
\text { - Maize yield }\left(\mathrm{t} \mathrm{ha}^{-1}\right) \\
\text { - Maize yield }\left(\mathrm{t} \mathrm{farm}^{-1}\right) \\
\text { - Maize type } \\
\text { - Income }\end{array}$ \\
\hline
\end{tabular}




\subsection{Use of APSIM model to predict maize yield}

The APSIM model estimated maize yield gaps in Nyakiliba (Fig. 5). The approach compared the actual farmer yield with the attainable yield in the specific location. The average maize yield gap estimated in Nyakiliba $\left(4.6 \mathrm{t} \mathrm{ha}^{-1}, 57 \%\right.$ of total potential yield) was slightly higher compared with the records across the country of $3.03 \mathrm{tha}^{-1}$ (Niyitanga et al. 2015), but it was much larger in Gashora. The difference is due to the methodology used in the latter study. In this study, the yield gap was computed as the national average yield gap while the estimate from our study was done in a specific location with particular conditions. The level of yield gap was much larger in Gashora $\left(5.1 \mathrm{tha}^{-1}\right)$, in the range of $80 \%$ of potential yield. The calculation of yield gaps may differ from one author to another due to the methodological approach used and also depending on the reference yield against which to compare the actual yield (Affholder et al. 2013; Tittonell et al. 2010). Niyitanga et al. (2015), computing from the differences between the potential yield and the actual farmer yield, estimated the gap in percentage for maize to be in the range of $60.7 \%$. In the region, Tittonell et al. (2008) reported average maize (Zea mays L.) yield in Kenya to be around $25 \%$ of the water-limited yield.

\section{Conclusion and recommendation}

The present study aimed to assess the extent of maize yield gap and the factors that contribute to low maize yields in farmers' fields. A contribution of biophysical and socioeconomic factors to maize yield gap was assessed in two districts, falling under two different agro-ecological zones in Northern and Southern parts of Rwanda. We show that the maize yield gap is explained by various factors associated with input nutrients and social-economic, and that the extent of yield gap is location specific. Both biophysical and socialeconomic factors may play explanatory roles. Addressing yield gap requires optimal use of inputs.

Use of NDVI indicates flexibility to predict maize yield in farmer fields in a specific location and correlates with major crop nutrient resources (N and P). The APSIM model was successfully used to determine the yield gap by measuring the difference between the potential maize yield and the actual farmer yield. The maize yield gap was estimated to be in the range of $57 \%$ in Nyakiliba where the response of maize grain yield to $\mathrm{N}$ fertilizer was adequately simulated and additional $\mathrm{N}$ inputs are required to reach the optimum of $4.6 \mathrm{t} / \mathrm{ha}$. The increase of agricultural productivity in smallholder farms depends largely on the efficient use of available inputs. Supply of sufficient nutrients to plants is critical and their availability may heavily affect crop productivity. It is clear that applying correct soil nutrients and adequate management strategies will translate into subsequent additional food production towards sustainable improvements in food security and additional income for farmers. Yield gaps associated with particular farmer management strategies should therefore be monitored and further consideration be given to in-season predictions using NDVI. Such strategies could assist in addressing yield gaps (especially through nutrient management) in the context of crop intensification programme (CIP) and improve food security. By implementing these strategies, conditions are created to significantly raise productivity, reduce on-farm yield gaps and promote exports, and increase farm revenues. Efforts to develop objective-based approaches and methods aiming at reducing the crop yield gap should aim to supporting the research and extension services in the country. The country presents diversity in farming systems caused by differences in agro-ecological zones and socio-economic conditions that would determine the sitespecific crop yield gap. The determination of yield gaps at the location level and associated factors is paramount in the efforts to increase on-farm productivity in the country.

Acknowledgements We are grateful to the University of Rwanda (UR) and farmers from both Nyakiliba and Gashora for their generous collaboration. We appreciate comments by anonymous reviewers on earlier drafts of this manuscript.

Funding information This work was funded by the Swedish International Development Cooperation Agency (Sida). The research received a technical support of the Trees-for-Food-Security project (http://aciar.gov.au/ aifsc/projects/trees-food-security-improving-sustainable-productivityfarming-systems-and-evergreen), under the auspices of the CGIAR research programme on Forests, Trees, and Agroforestry, with the financial support from ACIAR (Project FSC/2012/014) and project partners (including CSIRO).

\section{Compliance with ethical standards}

Conflict of interest The authors declare that they have no conflict of interest.

Open Access This article is licensed under a Creative Commons Attribution 4.0 International License, which permits use, sharing, adaptation, distribution and reproduction in any medium or format, as long as you give appropriate credit to the original author(s) and the source, provide a link to the Creative Commons licence, and indicate if changes were made. The images or other third party material in this article are included in the article's Creative Commons licence, unless indicated otherwise in a credit line to the material. If material is not included in the article's Creative Commons licence and your intended use is not permitted by statutory regulation or exceeds the permitted use, you will need to obtain permission directly from the copyright holder. To view a copy of this licence, visit http://creativecommons.org/licenses/by/4.0/.

\section{References}

Affholder, F., Poeydebat, C., Corbeels, M., Scopel, E., \& Tittonell, P. (2013). The yield gap of major food crops in family agriculture in the tropics: assessment and analysis through field surveys and modelling. Field Crops Research, 143, 106-118. 
Ahmad, I., Ghafoor, A., Bhatti, M. I., \& Akhtar, I.-u. H., \& Ibrahim, M. (2014). Satellite remote sensing and GIS-based crops forecasting \& estimation system in Pakistan. Crop monitoring for improved food security.

Atzberger, C. (2013). Advances in remote sensing of agriculture: Context description, existing operational monitoring systems and major information needs. Remote sensing, 5(2), 949-981

Beza, E., Silva, J. V., Kooistra, L., \& Reidsma, P. (2017). Review of yield gap explaining factors and opportunities for alternative data collection approaches. European Journal of Agronomy, 82, 206-222.

Bouyoucos, G. J. (1962). Hydrometer method improved for making particle size analyses of soils 1. Agronomy Journal, 54(5), 464-465.

Bray, R. H., \& Kurtz, L. (1945). Determination of total, organic, and available forms of phosphorus in soils. Soil Science, 59(1), 39-46.

Bucagu, C., Vanlauwe, B., Van Wijk, M. T., \& Giller, K. E. (2014). Resource use and food self-sufficiency at farm scale within two agro-ecological zones of Rwanda. Food security, 6(5), 609-628.

FAO. (2012). West African food composition table: In Foods ECOWAS/ WAHO and biodiversity international. Rome: Food and Agriculture Organization of the United States.

Gat, N., Erives, H., Fitzgerald, G. J., Kaffka, S. R., \& Maas, S. J. (2000). Estimating sugar beet yield using AVIRIS-derived indices. In Summaries of the 9th JPL Airborne Earth Science Workshop, 2000: unpaginated CD. Pasadena, CA: Jet Propulsion Laboratory.

Govaerts, B., \& Verhulst, N. (2010). The normalized difference vegetation index (NDVI) Greenseeker (TM) handheld sensor: toward the integrated evaluation of crop management part A: concepts and case studies. CIMMYT.

Holzworth, D., Huth, N. I., Fainges, J., Brown, H., Zurcher, E., Cichota, R., Verrall, S., Herrmann, N. I., Zheng, B., \& Snow, V. (2018). APSIM Next Generation: overcoming challenges in modernising a farming systems model. Environmental Modelling \& Software, 103, 43-51.

Kathiresan, A. (2011). Strategies for sustainable crop intensification in Rwanda. Shifting focus from producing enough to producing surplus.

Kathiresan, A. (2012). Farm land use consolidation in Rwanda. Kigali: Republic of Rwanda, Ministry of Agriculture and Animal Resources.

Kayiranga, D. (2006). The effect of land factors and management practices on rice yields. In 2006. ITC.

Kelly Wanda, R.S.B. Ferris, Mary Rucibango, Jacqueline Tuyisenge, Domitile Mukankubana, Boniface Kagiraneza, et al. (2002). Maize sub-sector market survey, CIAT-ATDT/ISAR/IITA-FOODNET and PEARL Project-Rwanda. Kigali, Rwanda.

Leng, G., \& Huang, M. (2017). Crop yield response to climate change varies with crop spatial distribution pattern. Scientific Reports, 7(1), $1-10$.

Liu, Z., Yang, X., Hubbard, K. G., \& Lin, X. (2012). Maize potential yields and yield gaps in the changing climate of Northeast China. Global Change Biology, 18(11), 3441-3454.

MINAGRI. (2014). Annual report for year 2012/2013. Rwanda: Kigali.

Ndoli, A., Baudron, F., Schut, A. G., Mukuralinda, A., \& Giller, K. E. (2017). Disentangling the positive and negative effects of trees on maize performance in smallholdings of Northern Rwanda. Field Crops Research, 213, 1-11.
Niyitanga, F., Kabayiza, A., \& Pierre, N. J. (2015). Assessment of yield gaps in main staple crops in Rwanda. International Journal of Agriculture Innovations and Research, 3(4), 1267-1271.

Ray, S., Singh, J., Dutta, S., \& Panigrahy, S. (2003). Analysis of withinfield variability of crop and soil using field data and spectral information as a pre-cursor to precision crop management. International Archives of Photogrammetry Remote Sensing and Spatial Information Sciences, 34(7/A), 302-307.

Ray, D. K., Mueller, N. D., West, P. C., \& Foley, J. A. (2013). Yield trends are insufficient to double global crop production by 2050 . PLoS One, 8(6), e66428.

Shepherd, K., Ohlsson, E., Okalebo, J., \& Ndufa, J. (1995). Potential impact of agroforestry on soil nutrient balances at the farm scale in the East African Highlands. Fertilizer Research, 44(2), 87-99.

Sileshi, G., Akinnifesi, F. K., Debusho, L. K., Beedy, T., Ajayi, O. C., \& Mong'omba, S. (2010). Variation in maize yield gaps with plant nutrient inputs, soil type and climate across sub-Saharan Africa. Field Crops Research, 116(1-2), 1-13.

Smethurst, P. J., Huth, N. I., Masikati, P., Sileshi, G. W., Akinnifesi, F. K., Wilson, J., \& Sinclair, F. (2017). Accurate crop yield predictions from modelling tree-crop interactions in gliricidia-maize agroforestry. Agricultural Systems, 155, 70-77.

Teal, R., Tubana, B., Girma, K., Freeman, K., Arnall, D., Walsh, O., et al. (2006). In-season prediction of corn grain yield potential using normalized difference vegetation index. Agronomy Journal, 98(6), $1488-1494$.

Thornton, P. K., \& Herrero, M. (2001). Integrated crop-livestock simulation models for scenario analysis and impact assessment. Agricultural Systems, 70(2-3), 581-602.

Tittonell, P., Vanlauwe, B., Corbeels, M., \& Giller, K. E. (2008). Yield gaps, nutrient use efficiencies and response to fertilisers by maize across heterogeneous smallholder farms of western Kenya. Plant and Soil, 313(1-2), 19-37.

Tittonell, P., Corbeels, M., Van Wijk, M. T., \& Giller, K. E. (2010). FIELD - a summary simulation model of the soil-crop system to analyse long-term resource interactions and use efficiencies at farm scale. European Journal of Agronomy, 32(1), 10-21.

Trumbo, P., Schlicker, S., Yates, A., \& Poos, M. (2002). Food and Nutrition Board of the Institute of Medicine, The National Academies. Dietary reference intakes for energy, carbohydrate, fiber, fat, fatty acids, cholesterol, protein and amino acids. Journal of the American Dietetic Association, 102(11), 1621-1630.

Tucker, C. J., Holben, B. N., Elgin Jr., J. H., \& Mcmurtrey III, J. E. (1980). Remote sensing of total dry-matter accumulation in winter wheat. NASA TM, 80631.

Van Ittersum, M. K., Cassman, K. G., Grassini, P., Wolf, J., Tittonell, P., \& Hochman, Z. (2013). Yield gap analysis with local to global relevance - a review. Field Crops Research, 143, 4-17.

Verdoodt, A., \& Ranst, E. V. (2003). Land evaluation for agricultural production in the Tropics: a large-scale land suitability classification for Rwanda Krijgslaan 281 S8, B-9000. Gent, Belgium: Laboratory of Soil Science, Ghent University.

Walkley, A., \& Black, I. A. (1934). An examination of the Degtjareff method for determining soil organic matter, and a proposed modification of the chromic acid titration method. Soil Science, 37(1), 29 38. 


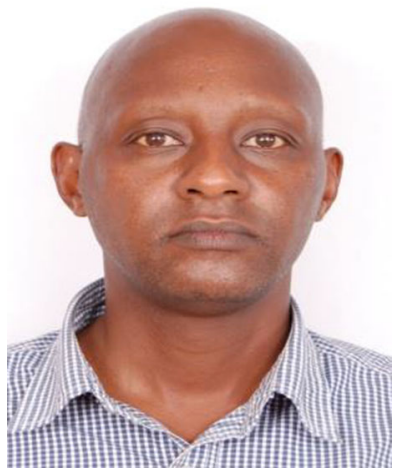

Dr. Bucagu Charles is the current Deputy Director General of Rwanda Agriculture Board in Rwanda. Over the last 10 years, Charles's research has focused on smallholder farming systems in Rwanda with particular emphasis on exploring the diversity of mixed based farming systems within different agro-ecological zones and identifying the role of agroforestry in addressing problems related to soil nutrient deficiencies and poor quality of livestock feeds. Particular emphasis is accorded to issues regarding resource use and exploring options for optimizing resource use on farms. He has been in teaching and research involving use of trees and shrubs in particular farming environments, targeting appropriate options for integration in agricultural production systems. He has a vast experience in training and student supervision and is involved in a vast network of scientists with the view of building partnership to develop research for impact in rural communities.

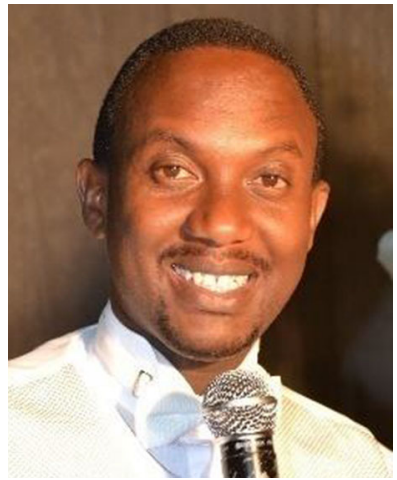

Dr. Ndoli Alain is a senior programme officer at the International Union for Conservation of Nature. He holds a Ph.D. in agroforestry from Wageningen University. From 2010 to 2013, he has been involved in lecturing at the University of Rwanda and conducted research on the reclamation of coltan-mined sites. He worked with World Agroforestry Centre (ICRAF) and the International Maize and Wheat Improvement Centre (CIMMYT) from 2013 to 2017 in different projects and has published a number of peer-reviewed scientific articles. He is passionate about resilience and sustainability of farming systems and agroforestry in developing countries.

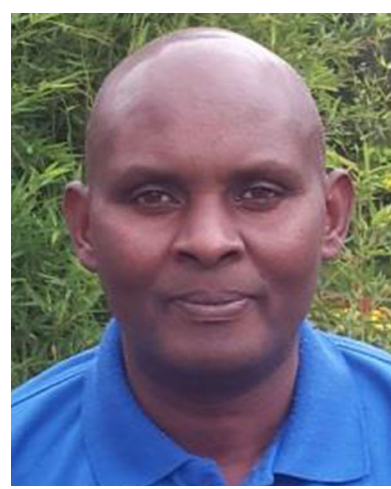

Cyamweshi R. Athanase is a soil scientist researcher working for Rwanda Agriculture and Animal Resources Development Board (RAB) in the Department of Land Husbandry, Irrigation and Integrated Soil Fertility Management. He is currently pursuing a doctoral training with Jomo Kenyatta University of Agriculture and Technology in Kenya since 2018. His work focuses on assessing the potential of agroforestry to impact food security and to offer the environmental service of carbon sequestration in Rwanda.

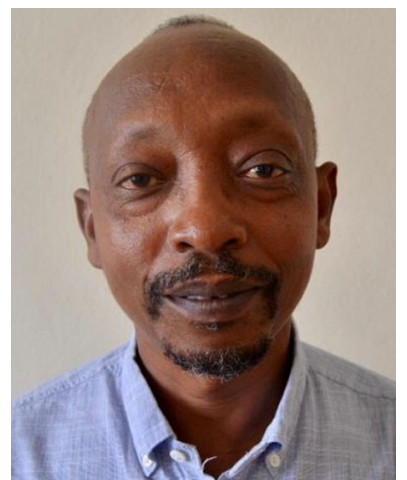

Dr. Leon N. Nabahungu was born on 26 July 1966 in Bukavu, Democratic Republic of the Congo (DR Congo). In 1983, he entered the University of Yangambi (Institut des Sciences Agronomiques) and obtained a degree of Ingenieur Agronome with specialization in Soil Sciences in 1993. In 1995, he was employed at the Institute of Agricultural Sciences of Rwanda (ISAR, Rwanda) which later became Rwanda Agriculture Board (RAB) in 2011 as a research assistant and Head of the research programme. He earned his Ph.D. in 2012 at Wageningen University, the Netherlands. In 2014, he was enrolled at IITABukavu as post doc and upgraded to associate scientist in 2017. He has been lecturing at the National University of Rwanda (NUR) and UCB in Bukavu. He has extensively been involved in consultancy work in the area of Soil Fertility and Land Management and has published more than 30 peer-reviewed papers, books, book chapters, and conference proceedings. 


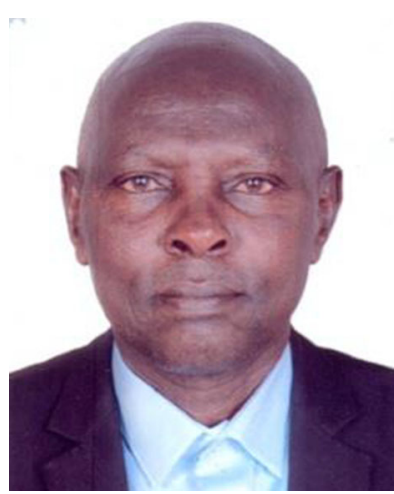

Dr. Athanase Mukuralinda was born on 15 September 1963 in the Democratic Republic of the Congo at the Masisi area. He is a senior scientist with a Ph.D. in agroforestry. He has a vast experience in soil fertility management and nutrient cycling in agroforestry systems. $\mathrm{He}$ is the ICRAF Country Representative and oversees all ICRAF projects conducted in Rwanda. He is the author of more than 30 papers in peer-reviewed journals and technical publications.

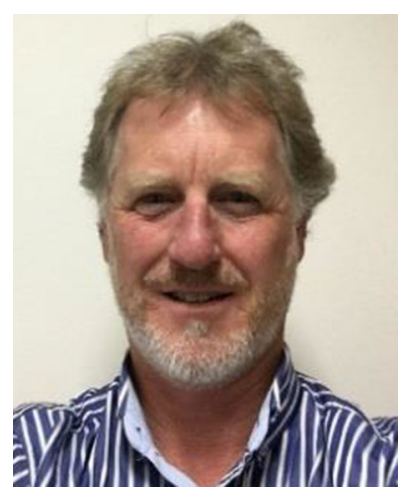

Dr. Philip Smethurst is a soil and water scientist in agriculture and forestry. Dr. Philip Smethurst graduated from the University of Melbourne and University of Florida with expertise in soil, hydrology, agriculture, forestry, and plant nutrition. His experimentation and modelling span almost four decades, and he currently leads or works on projects in South America, Africa, and Australia. His current research links systems understanding, modelling, real-time data, plotscale food and wood production, catchment scale hydrology, and codes of practice. 